\title{
Seasonal Fluctuation and Population Distribution of Otocryptis wiegmanni, Wagler, 1830 (Reptilia: Agamidae) Inhabiting a Tropical Lowland Rain Forest of Sri Lanka
}

\author{
D.M.K. Dharani ${ }^{1}$, W.A.D. Mahaulpatha ${ }^{1 *}$ and Anslem De Silva ${ }^{2}$ \\ ${ }^{1}$ Department of Zoology, University of Sri Jayewardenepura, Nugegoda, Sri Lanka \\ ${ }^{2}$ Amphibia and Reptile Research Organization of Sri Lanka (ARROS), Gampola, Sri Lanka
}

Date Received 01-10-2018_ Date Accepted: 25-10-2018

\begin{abstract}
The seasonal fluctuations of population density and distribution of Otocryptis wiegmanni inhabiting indifferent habitats of the Yagirala forest reserve of Sri Lanka was investigated during the north-east, first inter-monsoon, south-west and second inter-monsoon seasons of the year 2014. Three linear transacts, each measuring $200 \mathrm{~m}$ in length were marked along the natural forest, degraded forest and riverine forest habitats. All transects were surveyed by visual encounter survey (VES) method. Ambient temperature, relative humidity, canopy cover and leaf litter moisture content were measured in three points of each transect $(50,100$ and $150 \mathrm{~m})$ and the monthly total rainfall data was obtained from Meteorological Department. The highest mean adult population density and the highest number of juveniles were recorded during the relatively dry north-east monsoon season. $O$. wiegmanni preferred the degraded forest habitat $\left(0.027 \pm 0.020 \mathrm{lizards} / \mathrm{m}^{2}\right)$ compared to the natural $\left(0.007 \pm 0.006\right.$ lizards $\left./ \mathrm{m}^{2}\right)$ and riverine forest habitats during all four climate seasons. Fluctuations in the population density varied according to season and habitat conditions. This species fed mostly on insects of the Orders Orthoptera, Coleoptera and Hymenoptera, and the common breeding season was during the north-east monsoon (NEM) in January-February period.
\end{abstract}

Key words: Yagirala forest reserve, agamid, kangaroo lizard, habitat preference

\section{Introduction}

Currently the genus Otocryptis in Sri Lanka consists of two species, $O$. wiegmanni and $O$. nigristigma both endemic to the island. The former is mainly confined to the wet and intermediate climatic zones whilst $O$. nigristigma occurs mainly in the dray zone. O. wiegmanni inhabits in tropical, moist, lowland rain forests. They can be found on the forest floor, rocks, the roots of large trees, low vegetation and even on boulders along streams from sea level to 1,300 $\mathrm{m}$ (de Silva and Ukuwela, 2017). Additionally it is found in degraded forests, plantations, rural and urban home gardens (Pahathkumbura et al., 1996; Bahir and Surasinghe, 2005; Maduwage and Silva, 2012)

\footnotetext{
${ }^{*}$ Correspondence: mahaulpatha@yahoo.com

(C) University of Sri Jayewardenepura
} 
where there is adequate leaf litter and shade. It is a small slender lizard which can be distinguished from other Sri Lankan agamids by its' distinct maroon patch present laterally on the dewlap of males body and long hind limbs (De Silva and Gunewardene, 2005; Somaweera and Somaweera, 2009). They are terrestrial lizards that quickly run when disturbed using bipedal gait (ManamendraArachchi and Liyanage, 1994). Adults usually sleep hanging from the forelimb on slender twigs (Somaweera and Somaweera, 2009). O. wiegmanni mainly feeds on ants, ground moths, grasshoppers, spiders, small geckos and beetles and occasionally on plant materials like tender shoots (De Silva et al., 2004). Males display territorialism and fight with invading males by flicking the dewlap in quick succession (Karunarathna and Amarasinghe, 2008).

Domestic cats, poultry and the common coucal (Centropus sinensis) are the known predators of agamids, geckos, skinks and snakes (de Silva, 1996). According to de Silva (1996) O. weigmanni has been recorded being killed by domestic cats. Although $O$. wiegmanni is widely distributed in the wet zone of Sri Lanka its seasonal fluctuation of population density and distribution in tropical forests is unknown. Thus the present study attempts to fill this knowledge gap with the objective of contributing to the effective conservation of the species.

\section{Materials and Methods}

\subsection{Study site}

The study was conducted at the Yagirala rain Forest Reserve, located in the Western province of Sri Lanka $\left(6^{0} 21^{\prime}\right.$ to $6^{0} 26^{\prime} \mathrm{N}$ and $80^{\circ} 06^{\prime}$ to $\left.80^{\circ} 11^{\prime} \mathrm{N}\right)$ from January to December, 2014. It is a tropical lowland rain forest with an area of 2004 ha. The elevation ranges from 10 to $26 \mathrm{~m}$ above MSL. The dominant habitat types are the natural forests degraded forests and riverine forest habitats. Pine plantations (Pinus caribaea) were present adjacent to the main forest habitats.

\subsection{Survey of Lizards}

The three main habitats; natural, degraded and riverine forest within the Yagirala Forest Reserve were identified using digital maps. O. wiegmanni census was carried out by visual encounter survey method along three fixed length path transects of $200 \mathrm{~m}$ in each habitat. Transect length and width was determined using measuring tapes and were marked with tapes tied to the vegetation. Due to the complex vegetation structure and the possible bias caused by variation in visibility between species and transects, only those lizards observed within $3 \mathrm{~m}$ path of the habitat (1.5 $\mathrm{m}$ on each side of the transect) were recorded.

All transects were surveyed hourly from $06.00 \mathrm{~h}$ to $18.00 \mathrm{~h}$ for six days per season during the four monsoon seasons; northeast (NEM) (January-February), first inter-monsoon FIM) (MarchApril), southwest (SWM) (May-June) and second inter-monsoon season (SIM) (OctoberNovember). Transects were surveyed by two observers who walked slowly $(3-4 \mathrm{~m} / \mathrm{min})$ carefully searching the dense vegetation and the forest floor on both sides of the transect line. Tree bases, trunks, branches and shrub plants were checked and rocks and logs were overturned and leaf litter on the ground was disturbed with snake hooks to expel hidinglizards. O. wiegmanni recorded along these transacts were identified using "Lizards of Sri Lanka: A color guide with field keys" (Somaweera and Somaweera, 2009) and hand captured to take measurements (Howells, 2013). 
O. wiegmanni was categorised into three discrete classes as adult male, and female and juvenile based on the approximate snout to vent length (length from tip of snout to the anterior margin of cloaca), tail length (length from tip of tail to the anterior margin of cloaca) (Planka, 1971), weight, coloration and obvious secondary sexual characteristics such as presence or absence of gular sac. Snout to vent length and tail length were measured to nearest $0.1 \mathrm{~mm}$ by a vernier caliper (Sudasinghe and Kusuminda, 2013) and live wet weight to nearest $0.1 \mathrm{~g}$ was measured using a weighing scale (Planka, 1971).

\subsection{Habitat variables}

Six habitat variables were recorded along transect at 50, 100 and $150 \mathrm{~m}$. Ambient temperature at breast height above ground in shade was measured to the nearest $0.10^{\circ} \mathrm{C}$ using a bulb thermometer (Planka, 1971). Relative humidity at breast height (DBH) above ground in each transect were recorded using weather meter (Kestrel 400, USA) (Blair, 2009). Canopy cover was measured using a $2.5 \mathrm{~cm}$ diameter tube on which a grid drawn on a polythene paper was fixed. All squares that cover more than $50 \%$ when vertically looking up at the canopy cover were counted and percentage values were calculated. The litter depth was measured by inserting a metal ruler vertically into the litter until the ground was felt. Leaf litter moist content was measured during each sampling day. Monthly total rainfall recorded at the Mathugama agronomy station during the research period was obtained from the Department of Meteorology, Colombo, Sri Lanka.

\section{Results}

Population densities of $O$. wiegmanni during the four climatic seasons are given in Table 1. There was a significant difference in population density of $O$. wiegmanni during the four climate seasons (ANOVA, $\mathrm{p}<0.05$ ). The highest mean population density $0.04 \pm 0.02$ lizards $/ \mathrm{m}^{2}$ was recorded in NEM and the lowest population density $0.0 \pm 0.01$ lizards $/ \mathrm{m}^{2}$ was recorded during SIM. A gradual decrease in the population density was observed from NEM to SIM.

Table 1: Seasonal fluctuation of mean population density of $O$. wiegmanni in Yagirala Forest Reserve ( $n=6)$.

\begin{tabular}{lc}
\hline Climate Season & $\begin{array}{c}\text { Mean population density } \\
\left(\text { lizards } / \mathrm{m}^{2}\right)\end{array}$ \\
\hline North-East Monsoon season & $0.04 \pm 0.02^{\mathrm{b}}$ \\
First Inter Monsoon season & $0.03 \pm 0.02^{\mathrm{a}}$ \\
South West Monsoon season & $0.02 \pm 0.01^{\mathrm{a}}$ \\
Second Inter Monsoon season & $0.01 \pm 0.01^{\mathrm{a}}$ \\
Probability & $\mathrm{P}<0.05$ \\
\hline
\end{tabular}

Different superscripts in the same column indicate significant differences $(\mathrm{p}<0.05)$ at $95 \%$ probability level according to the Tukey's test.

The seasonal population density fluctuation of $O$. wiegmanni in different habitat types is given in Table 2. Degraded forest habitat had the highest population density and the natural forest habitat had the lowest density. Population density in the degraded forest habitat during the four climatic seasons was significantly different (AVOVA, $\mathrm{p}<0.05$ ). Highest mean population density 
in the degraded forest was observed during the NEM $\left(0.073 \pm 0.006\right.$ lizards $\left./ \mathrm{m}^{2}\right)$ and the lowest population density $\left(0.022 \pm 0.006\right.$ lizards $\left./ \mathrm{m}^{2}\right)$ was recorded during the SIM. O. wiegmanni population density during the four climate seasons in the Riverine forest habitat was significantly different (AVOVA, $\mathrm{p}<0.05$ ). In Riverine forest habitat, the highest mean $O$. wiegmanni population density $\left(0.04 \pm 0.02\right.$ lizards $\left./ \mathrm{m}^{2}\right)$ was recorded during the NEM and the lowest mean population density $\left(0.01 \pm 0.01\right.$ lizards $\left./ \mathrm{m}^{2}\right)$ was recorded during the SIM. The highest mean population density in natural forest habitat was recorded during the NEM $\left(0.02 \pm 0.01\right.$ lizards $\left./ \mathrm{m}^{2}\right)$ and the lowest mean population density was recorded in SIM $\left(0.004 \pm 0.01\right.$ lizards $\left./ \mathrm{m}^{2}\right)$. Lizard population density fluctuation among four climate seasons in natural forest habitat was significantly different (AVOVA, p<0.05).

Table 2: Seasonal fluctuation of $O$. wiegmanni population density among three habitat types (Lizards $\left./ \mathrm{m}^{2}\right)$.

\begin{tabular}{lcccc}
\hline Habitat & NEM & FIM & SWM & SIM \\
\hline Natural forest habitat & $0.0217 \pm 0.0084$ & $0.0150 \pm 0.0024$ & $0.0083 \pm 0.0024$ & $0.0042 \pm 0.0062$ \\
Degraded forest habitat & $0.0733 \pm 0.0064$ & $0.0517 \pm 0.0047$ & $0.0250 \pm 0.0024$ & $0.0218 \pm 0.0064$ \\
Riverine forest habitat & $0.0358 \pm 0.0012$ & $0.0275 \pm 0.0035$ & $0.0125 \pm 0.0012$ & $0.0117 \pm 0.0074$ \\
\hline
\end{tabular}

Mean snout to vent length of juvenile $O$. wiegmanni was $2.21 \pm 0.62 \mathrm{~cm}$, adult female was $4.79 \pm 0.46 \mathrm{~cm}$ and adult male was $6.42 \pm 0.82 \mathrm{~cm}$. Tail length of juvenile $O$. wiegmanni was $4.24 \pm 1.05 \mathrm{~cm}$ and adult female was $12.67 \pm 1.60 \mathrm{~cm}$ and adult male was $15.39 \pm 2.08 \mathrm{~cm}$. Mean body weight of juvenile $O$. wiegmanni was $4.13 \pm 0.82 \mathrm{~g}$, adult female was $7.71 \pm 0.68 \mathrm{~g}$ and adult male was $12.56 \pm 0.76 \mathrm{~g}$ (Table 3 ).

Table 3: Morphometric measurements of $O$. wiegmanni in discrete age classes (Mean $\pm \mathrm{SD}$ ).

\begin{tabular}{lcccc}
\hline Age class & $\mathrm{n}$ & Snout to vent length $(\mathrm{cm})$ & Tail length $(\mathrm{cm})$ & Weight $(\mathrm{g})$ \\
\hline Juvenile & 317 & $2.21 \pm .62$ & $4.24 \pm 1.05$ & $4.13 \pm 0.82$ \\
Adult female & 197 & $4.79 \pm 0.46$ & $12.67 \pm 1.60$ & $7.71 \pm 0.68$ \\
Adult male & 202 & $6.42 \pm 0.82$ & $15.39 \pm 2.08$ & $12.56 \pm 0.76$ \\
\hline
\end{tabular}

The percentage number of individuals in three discrete age classes fluctuated seasonally. The highest percentage of juveniles $(59.57 \%)$ was recorded in NEM. During this period the percentage of adult females was less than the percentage of adult males. Lowest juvenile count was recorded in SIM (6.14\%). During this period the percentage of adult females was high compared to the adult male percentage (Table 4).

Table 4: Seasonal variation of percentage number of individuals in discrete age classes of $O$. weigmanni.

\begin{tabular}{lcccc}
\hline Habitat & NEM & FIM & SWM & SIM \\
\hline Juvenile & 59.57 & 36.10 & 12.64 & 6.14 \\
Adult Female & 16.25 & 23.47 & 15.88 & 14.44 \\
Adult Male & 24.19 & 23.47 & 16.61 & 9.75 \\
\hline
\end{tabular}

NEM=Northeast monsoon; FIM=First inter monsoon, SWM=Southwest monsoon, SIM=Second inter monsoon. 
Among the four climate seasons, the minimum mean rainfall of $67.00 \mathrm{~mm}$ was received in NEM and the maximum mean rainfall of $510.5 \mathrm{~mm}$ was received in SWM. The entire forest was comparatively a dry during the first four months which included NEM and FIM due to the low rainfall. The forest was comparatively wet during the rest of the year due to the higher rainfall received during SWM and SIM (Fig. 1).

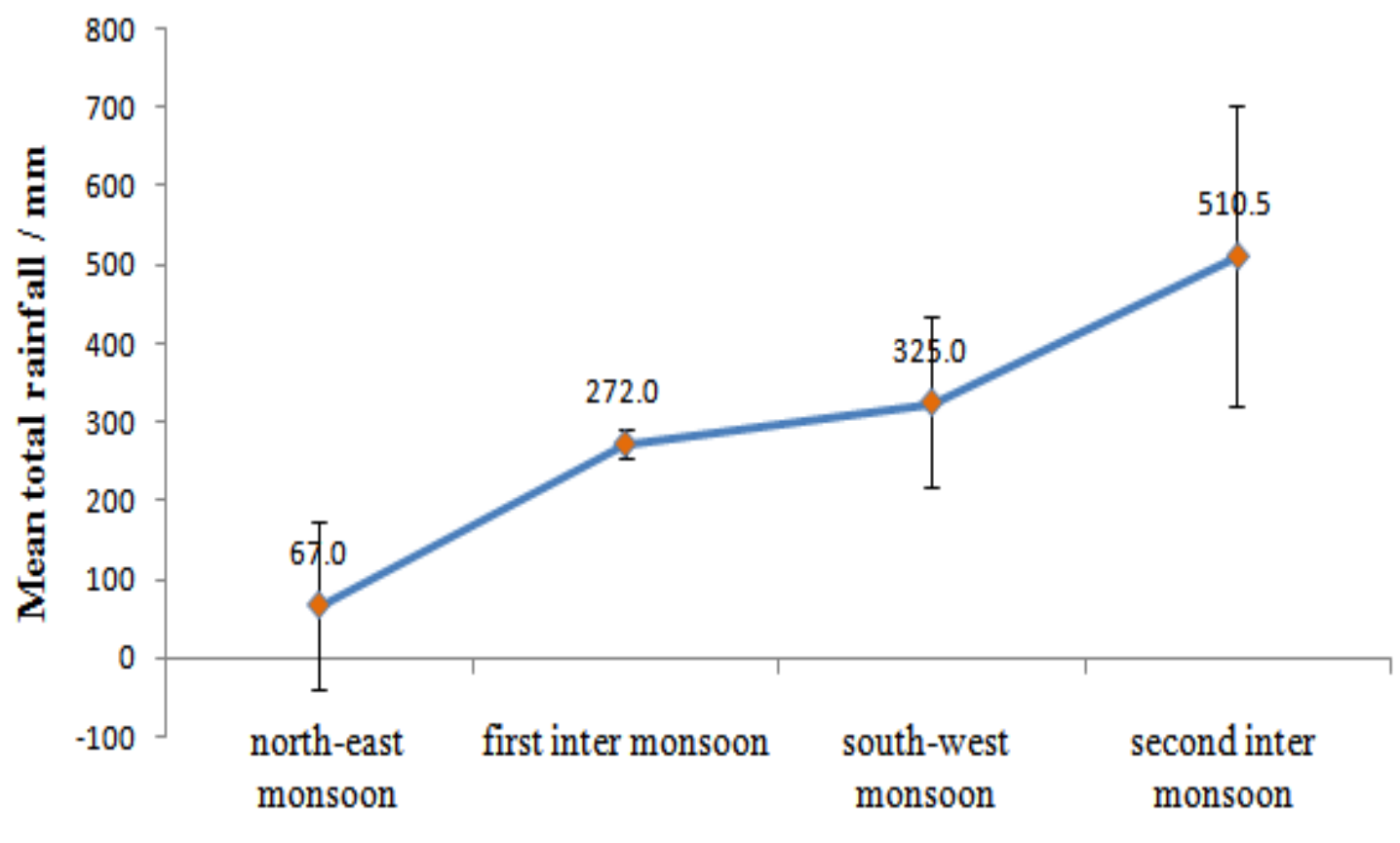

Climatic season

Figure 1: Seasonal variation of mean rainfall during the study period.

The ambient temperature differed significantly during the four climate seasons in each habitat (ANOVA, $\mathrm{p}<0.05$ ). However, the mean ambient temperature did not differ significantly among habitats. In all four climate seasons degraded forest habitat had the highest mean ambient temperature. The highest mean ambient temperature was recorded in NEM and the lowest mean ambient temperature was recorded in SIM in all the habitats studied. During FIM and SWM moderate mean ambient temperatures were recorded in each habitat (Table 5). In all four seasons degraded forest habitat had the lowest mean relative humidity. The lowest mean relative humidity in each habitat was recorded in NEM and the highest mean relative humidity was recorded in SIM (Table 6). 
Table 5: Seasonal variation of mean ambient temperature in Yagirala forest reserve from Jan -Dec $2014(\mathrm{n}=18)$.

\begin{tabular}{lccc}
\hline Climate season & $\begin{array}{c}\text { Degraded forest } \\
\text { habitat }\end{array}$ & $\begin{array}{c}\text { Riverine forest } \\
\text { habitat }\end{array}$ & $\begin{array}{c}\text { Natural forest } \\
\text { habitat }\end{array}$ \\
\hline North-east monsoon season & $31.16 \pm 0.95^{\mathrm{a}}$ & $30.84 \pm 1.14^{\mathrm{a}}$ & $30.61 \pm 1.21^{\mathrm{a}}$ \\
First inter-monsoon season & $30.11 \pm 0.84^{\mathrm{b}}$ & $30.06 \pm 0.88^{\mathrm{a}}$ & $30.00 \pm 0.81^{\mathrm{b}}$ \\
South-west monsoon season & $29.52 \pm 0.84^{\mathrm{c}}$ & $29.35 \pm 0.79^{\mathrm{b}}$ & $29.21 \pm 0.75^{\mathrm{c}}$ \\
Second inter-monsoon & $28.27 \pm 0.95^{\mathrm{d}}$ & $27.76 \pm 1.65^{\mathrm{c}}$ & $28.80 \pm 1.34^{\mathrm{d}}$ \\
season & $\mathrm{P}<0.05$ & $\mathrm{P}<0.05$ & $\mathrm{P}<0.05$ \\
Probability & & &
\end{tabular}

Different superscripts in the same column indicate significant differences $(p<0.05)$ at $95 \%$ probability level (Tukey's test).

Table 6: Seasonal variation of $\%$ mean relative humidity during the study period $(n=18)$

\begin{tabular}{lccc}
\hline Climate season & $\begin{array}{c}\text { Degraded forest } \\
\text { habitat }\end{array}$ & $\begin{array}{c}\text { Riverine forest } \\
\text { habitat }\end{array}$ & $\begin{array}{c}\text { Natural forest } \\
\text { habitat }\end{array}$ \\
\hline North-east monsoon season & $65.65 \pm 7.12^{\mathrm{a}}$ & $65.94 \pm 3.97^{\mathrm{a}}$ & $67.03 \pm 2.99^{\mathrm{a}}$ \\
First inter-monsoon & $77.80 \pm 14.96^{\mathrm{b}}$ & $78.46 \pm 2.11^{\mathrm{b}}$ & $78.35 \pm 15.94^{\mathrm{b}}$ \\
South-east monsoon season & $90.21 \pm 0.88^{\mathrm{c}}$ & $94.53 \pm 2.11^{\mathrm{c}}$ & $95.72 \pm 1.78^{\mathrm{c}}$ \\
Second inter-monsoon & $92.071 \pm 2.26^{\mathrm{c}}$ & $94.32 \pm 3.97^{\mathrm{c}}$ & $96.52 \pm 1.24^{\mathrm{c}}$ \\
season & $\mathrm{P}<0.05$ & $\mathrm{P}<0.05$ & $\mathrm{P}<0.05$ \\
Probability & $\mathrm{C}$ &
\end{tabular}

Different superscripts in the same column indicate significant differences $(p<0.05)$ at $95 \%$ probability level Tukey's test

The leaf litter moisture content in each habitat differed significantly according to the season (ANOVA, $\mathrm{p}<0.05)$. However, the leaf litter moisture content did not differ significantly among habitats. The leaf litter moisture content was minimum during the NEM and it was maximum during the SIM in each habitat. Degraded forest habitat had the minimum mean leaf litter moisture content while natural forest habitat had the maximum leaf litter moisture content (Table 7).

Table 7: Seasonal variation of leaf litter moisture content during the study period $(n=18)$

\begin{tabular}{lccc}
\hline Climate Season & $\begin{array}{c}\text { Degraded forest } \\
\text { habitat }\end{array}$ & $\begin{array}{c}\text { Riverine forest } \\
\text { habitat }\end{array}$ & $\begin{array}{c}\text { Natural forest } \\
\text { habitat }\end{array}$ \\
\hline North-east monsoon season & $7.96 \pm 0.51^{\mathrm{a}}$ & $9.64 \pm 0.38^{\mathrm{a}}$ & $11.26 \pm 0.67^{\mathrm{a}}$ \\
First inter-monsoon season & $10.23 \pm 2.01^{\mathrm{b}}$ & $12.13 \pm 1.78^{\mathrm{b}}$ & $13.938 \pm 1.13^{\mathrm{b}}$ \\
South-west monsoon season & $14.74 \pm 1.11^{\mathrm{c}}$ & $15.57 \pm 1.05^{\mathrm{c}}$ & $16.39 \pm 0.70^{\mathrm{c}}$ \\
Second inter-monsoon & $17.16 \pm 0.64^{\mathrm{d}}$ & $18.03 \pm 0.93^{\mathrm{c}}$ & $18.79 \pm 0.85^{\mathrm{d}}$ \\
season & $\mathrm{P}<0.05$ & $\mathrm{P}<0.05$ & $\mathrm{P}<0.05$ \\
Probability & $\mathrm{y}$ & $\mathrm{m}$ &
\end{tabular}

Different superscripts in the same column indicate significant differences $(\mathrm{p}<0.05)$ at $95 \%$ probability level Tukey's test. 
The percentage canopy cover did not vary significantly seasonally in each habitat (ANOVA, $\mathrm{p}>0.05$ ). However, the canopy cover differed significantly among the three habitat types (ANOVA, $\mathrm{p}<0.05$ ). Degraded forest habitat had the minimum canopy cover while the natural forest habitat had the maximum canopy cover in all four seasons. There was a negative relationship between the canopy cover and mean $O$. wiegmanni population density (Pearson correlation, $\mathrm{r}=-$ 0.474, p>0.05) (Fig. 2).

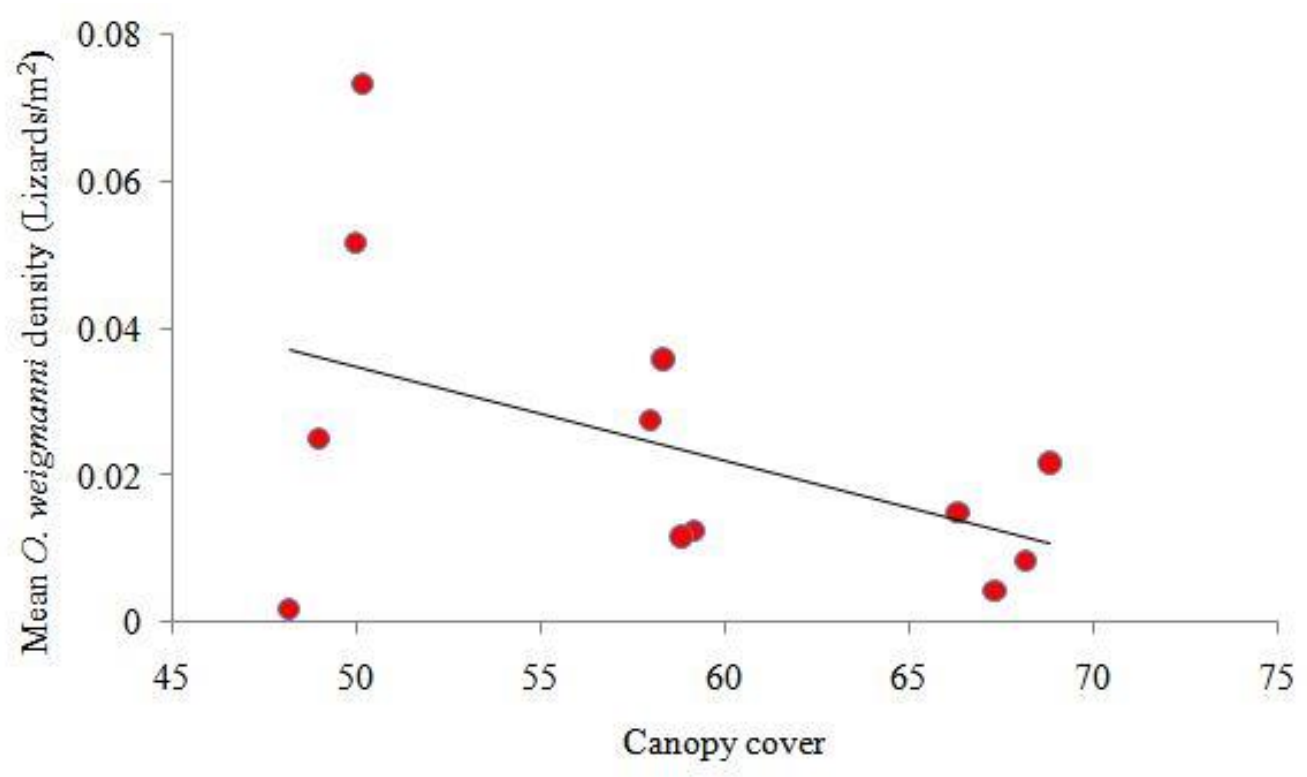

Figure 2: Relationship between canopy cover and mean $O$. wiegmanni population density.

Total number of 55 feeding behaviors was observed during the study period. Insects of three orders were recorded as pray species of $O$. weigmanni. They belonged to the orders Orthoptera, Coleoptera and Hymenoptera. Degraded forest habitat had the highest mean number of prey species and the natural forest habitat had the lowest mean number of prey species (Table 8).

Table 8: Variation of \% canopy in Yagirala forest reserve during the study period $(\mathrm{n}=18)$.

\begin{tabular}{lcccc}
\hline Habitat & NEM & FIM & SWM & SIM \\
\hline Degraded forest & $50.17 \pm 3.76^{\mathrm{a}}$ & $50.00 \pm 3.74^{\mathrm{a}}$ & $49.00 \pm 3.10^{\mathrm{a}}$ & $48.17 \pm 3.19^{\mathrm{a}}$ \\
Riverine forest & $58.33 \pm 4.13^{\mathrm{b}}$ & $58.00 \pm 4.20^{\mathrm{b}}$ & $59.17 \pm 2.93^{\mathrm{b}}$ & $58.83 \pm 3.56^{\mathrm{b}}$ \\
Natural forest & $68.83 \pm 2.14^{\mathrm{c}}$ & $66.33 \pm 3.27^{\mathrm{c}}$ & $68.17 \pm 2.32^{\mathrm{c}}$ & $67.33 \pm 3.13^{\mathrm{c}}$ \\
Probability & $\mathrm{P}<0.05$ & $\mathrm{P}<0.05$ & $\mathrm{P}<0.05$ & $\mathrm{P}<0.05$ \\
\hline
\end{tabular}

Different superscripts in the same column indicate significant differences $(p<0.05)$ at $95 \%$ probability level Tukey's test. 


\section{Discussion}

Population density of $O$. wiegmanni in the Yagirala forest reserve decreased from January to November in 2014 due to their differing activity levels during different seasons. The higher activity level and the population density recorded in NEM were due to the influx of juveniles during this period.

Present study revealed that $O$. Wiegmanni preferred the degraded forest habitat than the natural and riverine forest habitats. This is a surprising finding given the fact that most organisms prefer unaltered habitats. Degraded forest habitat had less canopy cover and more exposed areas where the lizards could expose themselves to the direct sunlight for thermoragulation. Therefore, being ectotherms, they may have preferred the degraded forest habit over the other habitat types where they could get optimal body temperatures to keep them more active. Population density was lowest in natural forest habitat as it maintained the lowest ambient temperature, highest relative humidity and highest leaf litter moisture content due to maximum canopy cover. Population density in riverine forest habitat was ranked second position compared to degraded forest habitat and natural forest habitat as it maintained values for habitat variables less favorable than degraded forest habitat but slightly greater than natural forest habitat due to moderate canopy cover.

The morphometric measurements of $O$. wiegmanni showed three discrete age class categories; the mean snout to vent length of juvenile $O$. wiegmanni was $2.21 \pm 0.62 \mathrm{~cm}$, adult female was $4.79 \pm 0.46 \mathrm{~cm}$ and adult male was $6.42 \pm 0.82 \mathrm{~cm}$ respectively without much color variation.

Digging the ground for egg laying was observed only during NEM which also recorded the highest number of juveniles. Therefore, it can be concluded that NEM (January-February) to be the main breeding season of $O$. wiegmanni in Yagirala Forest Reserve. Relatively drier weather conditions, higher temperatures, low leaf litter moisture and low mean relative humidity values that prevail in this season could be triggering the onset of breeding providing suitable conditions for incubation and egg hatching. According to de Silva et al. (2004) reproduction of O. wiegmanni takes place between July and January, with a peak between October and January. Results, of the present study was similar to that up to some extent since juveniles were observed in lesser numbers in other months as well. However, February was identified as a prominent breeding month along with January according to the results. As the breeding reached to a climax in North-East monsoon season adult females were less active than males. This trend is similar to previous studies done by Stamps (1983) and Cooper (1990) which suggest that during breeding season males risk more exposure to predators in order to find a mate and females may be less likely to risk exposure to predators during mating season because of reduced locomotory ability due to carrying eggs.

The negative correlation between canopy cover and mean $O$. wiegmanni density implied that, with decreasing canopy cover the lizard density was increased. Decreased canopy covers allow the habitats to be more exposed to sunlight. The significantly low canopy cover observed in the degraded forests compared to other habitats allowed sunlight to reach forest floor offering additional basking places for the lizards which may have indirectly contributed for the increase in their numbers in the degraded forests. This is further evident since a larger percentage of lizards preferred the direct sunlight when compared to shaded or dappled sunlight. The degraded forest habitat recorded the highest number of prey species of $O$. wiegmanni, mostly the insects of order 
Orthoptera, Coleoptera and Hymenoptera. Significantly lower canopy cover in degraded forest habitat should be the reason for higher insect abundance in concordance to the findings of Binckley and Resetarits (2009) on insect population in an open canopy. Barreto-Lima et al., (2013) has recorded a similar observation in a similar forest habitat. De Silva (2006) also suggests that $O$. wiegmanni has adapted to live in home gardens, plantations and degraded habitats. Present study further confirms this observation. Riverine forest habitat and natural forest habitat recorded lower densities of $O$. wiegmanni probably due to the lower ambient temperature, high relative humidity and high leaf litter moist content. These factors has increased generally in all the three habitats during rainy period of second inter-monsoon season (SIM) creating comparatively a wetter environment in the forest which supported the lowest population densities.

The findings of the present study help not only the conservation of this endemic species, but also effective conservation and management of Yagirala forest reserve as a whole.

\section{Acknowledgement}

We acknowledge Department of Forest Conservation Sri Lanka and Department of Wildlife Conservation for providing us the permission to conduct the research under the permits number R\&E/RES/2010/USJP and WL/3/2/17/14 respectively at Yagirala Forest Reserve, Department of Zoology, University of Sri Jayewardenepura for providing material support and the staff of Yagirala Research Center. We also acknowledge the assistance of Mr. S.S. Karunarathna and Mr. Daham Gunasekara, University of Sri Jayewardenepura.

\section{References}

Anslem de Silva 2006. Current status of the reptiles of Sri Lanka. In C.M.B. Bambaradeniya, (Ed) Fauna of Sri Lanka: Status of Taxonomy, Research and Conservation. The World Conservation Union, Colombo, 134-163pp.

Bahir M.M., Surasinghe T.D. 2005. A conservation assessment of the Sri Lankan Agamidae (Reptilia: Sauria). The Rafflet Bulletin of Zoology, 12: 407-412.

Barreto-Lima A.F., Pires E.O., De Sousa B.M. 2013. Activity, foraging mode and microhabitat use of Enyalius perditus (Squamata) in a disturbed Atlantic rainforest in southeastern Brazil. Salamandra, 49(4): 177-185.

Binckley C.A., Restarit W.J. 2009. Habitat selection determines abundance, richness and species composition of beetles in aquatic communities. Biology Letters, 1 (3), 370-374.

Blair C. 2009. Daily activity patterns and microhabitat use of a Helothermic lizard, Ameivaexsul (Squamata: Teiidae) in Puerto Rico. South American Journal of Herpetology, 4(2): 79-185.

Cooper W.A. 1990. Locomotor impairment and defense in gravid lizards (Eumeceslaticeps): behavioral shift in activity may offset costs of reproduction in an active forager. Behavioral Ecology and Sociobiology, 27: 153-157.

De Silva A. 1996. The Herpetofauna of Sri Lanka: a brief review. Graphic Land, Kandy.

De Silva A., Gunewardene S. 2005. Insect attacking Otocryptis weigmanni. The diversity of Dumbaramountain with special reference to herpetofauna. Lyriocephalus, 6(1-2): 79.

De Silva A., Das I., Bauer A.M., Goonewardene S. 2004. Vedda rock art in Sri Lanka depicting reptiles with special reference to the golden Gecko Calodactylodes illingworthorum (Reptilia: Gekkonidae). Lyriocephalis, 5: 213-220. 
Howells J. 2013. Microhabitat use of the eastern fence lizard (Sceloporus undulatus) on the White Sands ecotone. Spring, 4-6.

Karunarathna D.M.S.S., Amarasinghe A.A.T. 2008. Notes on the Territorial behavior of Otocriptisweigmanni Wagler 1830 (Reptilia: Agamidae: Draconinae). Herpetotropicos. 4(2): 79-83.

Maduwage K, Silva A. 2012. Hemipeneal morphology of Sri Lankan dragon lizards (Sauria: Agamidae). Ceylon Journal of Science, 41(2): 111-123.

Manamendra-Arachchi K., Liyanage S. 1994. Conservation and distribution of the Agamid lizards of Sri Lanka with illustrations of the extant species. Journal of South Asian Natural History, 1: 77-96.

Pahathkumbura M., Jayawickrama, A., Anslem de Silva. 1996. Otocryptis waigmanni: preliminary observations. Abstracts, International Conference on the Biology \& Conservation of the Amphibians \& Reptiles of South Asia. 23-24.

Planka E.R. 1971. Ecology of the agamid lizard Amphibolurus isolepis in Western Australia. Copeia, 3: 528-536.

Somaweera R., Somaweera N. 2009. Lizards of Sri Lanka: A colour guide with field keys. Serpent's Tale NHBD, Germany (Edition Chimaira), 20-92.

Stamps J.A. 1983. The relationship between ontogenetic habitat shifts, competition and predator avoidance in a juvenile lizard (Anolis aenus). Behavioral Ecology and Sociobiology. 12: 1933.

Sudasinghe B.S.A.T., Kusuminda T.G.T. 2013. Ovipositional behavior of Otocryptis weigmanni (Reptilia: Agamidae: Draconinae). Herpetotropicos. 9(1-2): 47-53. 